\title{
EFFECT OF CASEARIA SYLVESTRIS OIL IN CHRONIC INFLAMMATION INDUCED BY SYNTHETIC IMPLANTS IN MICE
}

\author{
EFEITO DO ÓLEO DE CASEARIA SYLVESTRIS NA INFLAMAÇÃO CRÔNICA INDUZIDA \\ POR IMPLANTES SINTÉTICOS EM RATINHOS
}

\author{
Natalia Lopes Viana ${ }^{1}$
}

ABSTRACT: Inflammation is a natural body's event that starts immediately when the body suffers a tissue injury. Its goal is to exterminate the noxious agent, however when the noxious agent is not removed and stands much longer, it is succeeded into a chronic inflammation, what is characterized by the persistence of harmful agent that can go on for days, months or years. When the chronic inflammation ends, it forms a fibrous tissue. This study we evaluated the effect of the essential oil of Casearia sylvestris used on the traditional medicine. Itis rich in a type of chemical class called sesquiterpene, which is characterized for its anti-inflammatory effect. The inflammatory componentwas measured by myeloperoxidase activity (MPO) and $\mathrm{N}$-acetyl- $\beta$-D-glicosaminidase (NAG) and mast cells account. For this purpose, 6r male mices $\mathrm{C}_{57 / \mathrm{B}_{1} / 6}$ (control group (saline), DMSO $1 \%$, iong, roong, and rooong, of $C$. sylvestris essential oil) underwent to a chronic inflammatory response induced by synthetic sponge and treated with these dosages. The results have showed that the inflammatory component, represented by the evaluation of MPO and NAG activity, had no significant difference between the three doses evaluated compared to the control group. According to the results, the chronic inflammation treated with C. sylvestris essential oil had no effect on inflammatory process.

Keywords: Chronic inflammation. Casearia sylvestris. Tissue repair.

RESUMO: A inflamação é um evento natural do corpo em resposta a uma lesão no tecido. Seu objetivo é exterminar o agente nocivo, porém, quando o agente nocivo não é removido, sucede-se à inflamação crônica, que se caracteriza pela persistência do agente nocivo que pode durar dias, meses ou anos. $\mathrm{O}$ resultado da inflamação crônica é a formação de um tecido cicatricial fibroso. Neste estudo avaliou-se o efeito do óleo essencial de casearia sylvestris utilizado na medicina tradicional. É rico em sesquiterpeno, que se caracteriza por seu efeito anti-inflamatório. A inflamação foi avaliada pela atividade da mieloperoxidase (MPO) e N-acetil- $\beta$-D-glicosaminidase (NAG) e contagem de mastócitos no tecido fibrótico. Para tanto, 6I camundongos machos $\mathrm{C}_{57}$ / BI / 6 foram subdivididos nos grupos: Controle (solução salina), DMSOı\%, ıo ng, ıoo ng e rooo ng, de óleo essencial de C. sylvestris. Os camundongos foram submetidos a uma resposta inflamatória crônica, induzida por uma esponja sintética introduzida na camada subcutânea do dorso dos animais, onde cada grupo recebeu seu respectivo tratamento. Os resultados mostraram que a atividade de MPO e NAG, não apresentou diferença significativa entre às três doses avaliadas em relação ao grupo controle. De acordo com os resultados, a inflamação crônica tratada com óleo essencial de C. sylvestris não teve efeito no processo inflamatório.

Palavras-chave: Inflamação crônica. Casearia sylvestris. Reparo de tecidos.

\section{INTRODUCTION}

\footnotetext{
${ }^{1}$ Bióloga (ISEED) e Bacharel em Ciência e Tecnologia de Alimentos (UFV). Mestra em Biologia Celular e Estrutural Aplicadas (UFU). Doutora em Biologia Celular e Estrutural (UNICAMP). E-mail: nataliaviana.ufv@hotmail.com.
} 
Inflammation is a natural and essential proportionate response by the immune system to ensure the survival of the tissue by a tissue injury caused by microbes, physical agents (radiation, trauma, burns), chemical (toxins, caustic substances), tissue necrosis and/or immune reactions, promoting the removal of noxious stimulus and the damaged tissue recovery (Chandrasekharan \& Sharma-Walia, 2015; Ahmed, 2011; Lima, Costa, Souza \& Gomes-Leal, 2007). Such tissue repair is driven by an endogenous mechanism, complex and balanced which is activated by events ordered and distinct. These consist of four steps, which occur superposed and integrated form: hemostasis, inflammation,

proliferation (also known as replication and the synthesis stage), and refurbishment (Guo \& DiPietro, 2010; Yussof, Omar, Pai \& Sood, 2012; Watson, 2012).

For most patients, the recovery of injured tissue occurs naturally without the need of medication, therapy or other interventions (Watson, 2012). However, a prolonged inflammation where the pathogenic agent is not removed, the inflammatory process progresses to chronic inflammation and can be highly detrimental to the organism (Lima, Costa, Souza \& Gomes-Leal, 2007). Many diseases involving chronic inflammation and represent the charge highest morbimortality in Brazil (Duncan et al., 2012). These diseases can cause tissue damage as occurs in multiple sclerosis, Alzheimer's disease, rheumatoid arthritis, systemic lupus erythematosus, cardiovascular diseases, cancer, chronic respiratory disease and diabetes (Duncan et al., 2012; Lima, Costa, Souza \& Gomes-Leal, 2007). Thus, therapeutic intervention becomes necessary (Gonçalves \& Parizotto, 1998), and thus it is understood the search for the possibility of facilitating or promoting normal tissue repair by optimizing the events involved in repair (Watson, 2012).

Studies folk medicine has gained prominence due to the number of information which provide the science. In the daily health practices, the application of scientific principles triggered the therapeutic discovery that improved the quality of life (França, Souza, Baptista \& Britto, 2008). Among the species with therapeutic potential, is Casearia sylvestris, whose medicinal extracts and isolated compounds is emphasized by their commonly known pharmacological potential (Ferreira et al., 20II). In folk medicine, the decoction of C. sylvestris sheet is prepared for both oral use and for topical application (Sassioto et al., 2004) applied to the treatment of canker sores, simple herpes, gastric ulcers, wounds, insect bites, treating topical wounds, burns, rashes, eczema and vitiligo. They are also used as wound-healing, antiseptic, antimicrobial, hemostatic, purifying blood and anti-inflammatory (Ferreira et al., 2orI; Marques, Simões, Ferreira, Santos \& Pessoa, 2013) (Capobiango, Vestena \& Bittencourt, 2009; Lipinski, de Figueiredo Wouk, da Silva, Perotto \& Ollhoff, 2012; Silva, Almeida \& Sousa, 2004).

For better scientific elucidation of the anti-inflammatory activity described about Casearia sylvestris on folk medicine, this study aims to evaluate tests (in vivo) of the essential oil effects on chronic inflammatory process, through assessments of biochemical changes and morphological involved in this process. 


\section{Materials and Methods}

\section{Animals}

For this study were used $6 \mathrm{r}$ mices, $\mathrm{C}_{57} / \mathrm{B}_{1} / 6$, males, 8 weeks old and weight around $30 \mathrm{~g}$. From total 32 animals were randomly separated for biochemical analysis and divided into 5 groups: control with saline (saline) and control with DMSO $\%$, both with 7 animals, and 3 groups with 6 animals each, treated with doses of ro, roo and rooong the essential oil of C. sylvestris.

For histological analysis, 29 animals were randomly divided and distributed in 5 groups: control group with saline solution (saline and control with DMSO 1\%, both with 7 animals, and 3 groups treated with doses of Io, Ioo and Iooong the essential oil of C. sylvestris.

The animals were kept in the depository of animals of the Department of Physiological Sciences/UFU, with free access to food and water, light/dark cycle, to his sacrifice.

\section{Essential oil of Casearia sylvestris}

The essential oil of C. sylvestris was provided By University of São Paulo (USP) - Diadema, as a lyophilized powder (49,2mg). To prepare the C. sylvestris stock solution, 49,2mg was dissolved in 49,2mL of DMSOı\%.

The doses preparing was based on the higher dose of C. sylvestris (Iooong/ı $\mu \mathrm{L}$ ): $100 \mu 1$ of $C$. sylvestris stock solution into $900 \mu \mathrm{l}$ of DMSOı\%. And for the doses of ıo and roong of $C$. sylvestris was made a serial dilution from the dose of rooong (

\section{Experimental model}

The project was approved by the Ethics Committee on the Use of Animals (CEUA) of the Federal University of Uberlândia/Minas Gerais under the protocol: CEUA No. 156-13. Chronic inflammation was induced by implantation of a synthetic matrix polyester-polyurethane (sponge) in the interscapular subcutaneous region of the mice.

\section{Sponge implantation technique}

The implant (polyester-polyurethane disks, $8 \mathrm{~mm}$ in diameter and $5 \mathrm{~mm}$ thick) were maintained in 70\% ethanol v / v for at least 24 hours prior to deployment and then boiled in distilled water for 30 minutes (Andrade, Fan \& Lewis, 1987; Araújo, Rocha, Mendes \& Andrade, 2010; Cassini-Vieira et al., 2014). The implantation procedure involved the prior application of $70 \mu \mathrm{L}$ of anesthesia intraperitoneal by xylazine (romg $/ \mathrm{kg}$ ) and ketamine (roomg/ $/ \mathrm{kg}$ ). Then it underwent to a dorsal epilation with an electric machine. After, the dorsal region was sterilized with cotton and alcohol $70 \% \mathrm{v} / \mathrm{v}$. The animals were placed on a surgical table for holding a dorsal midline incision on the skin of approximately $\mathrm{cm}$, made with a scalpel. 
It was later performed, the divulsion of the subcutaneous tissue with the help of a scissor of divulsion. In each animal was implanted a sponge disk, positioned approximately, $0.5 \mathrm{~cm}$ of the interscapular region, with the aid of a tweezers. The suture of the incision was made with nylon yarn using 3.o Donati point (Andrade, Fan \& Lewis, 1987; Araújo, Rocha, Mendes \& Andrade, 2oro; Cassini-Vieira, 2014). After recovering from anesthesia, the animals were disposed separately in cages with free water and food (Araújo, Rocha, Mendes \& Andrade, 2010; Cassini-Vieira, 2014).

\section{Treatment and removal of the implants}

The intra-implant treatment with $10 \mu \mathrm{L}$ each treatment occurred daily, from the times o- 8 days, via a local puncture, by $30 \mu \mathrm{L}$ syringe. On the 9 th day after implantation, the animals were euthanized by deep intraperitoneal anesthesia with $2 \mathrm{~mL}$ of thiopental ( $\mathrm{roomg} / \mathrm{kg}$ ). Thiopental was prepared 20 minutes before the procedure with addition of saline directly $30 \mathrm{~mL}$ vial. The sponge discs were removed by midline incision in the dorsal apical region, with the aid of scissors. Tweezers to remove muscle and adipose tissue that would possibly be attached to the sponge also was used. The sponges were placed in eppendorfs and then weighed and processed for biochemical and histological tests.

\section{Assessment of the myeloperoxidase (MPO) activity}

The myeloperoxidase activity was determined by the technique of (Bradley, Christensen \& Rothstein, 1982). After the dosage of hemoglobin, the precipitate was resuspended in 2.omL sodium phosphate buffer, $80 \mathrm{mM} \mathrm{pH}=6$. The samples were homogenized and transferred to Eppendorf $300 \mu \mathrm{L}$ and $600 \mu \mathrm{L}$ of added HTAB (Hexadecyltrimethylammonium Bromide - Sigma) $0.75 \% \mathrm{w} / \mathrm{v}$ diluted with $\mathrm{pH} 6$ phosphate buffer.

Samples were sonicated for ro seconds and centrifuged at $5000 \mathrm{rpm}$ for io minutes at $4^{\circ} \mathrm{C}$. The supernatant $(200 \mu \mathrm{L})$ was used for enzyme assay. The reaction follows the following orden: $100 \mu 1$ of $0.003 \%$ hydrogen peroxide; roo $\mu \mathrm{l}$ of TMB (3,3', 5,5' tetrametilbenzidine - Sigma) diluted to $6.4 \mathrm{mM}$ in DMSO (dimethyl sulfoxide - Merck) for I minute. It was added roo $\mu \mathrm{l}$ of $\mathrm{H}_{2} \mathrm{SO}_{4}$ (sulfuric acid - Merck) ${ }_{4} \mathrm{M}$ to stop the reaction. Then, $200 \mu \mathrm{L}$ were added to the 96 well plate and held in spectrophotometric reading at 45onm. The results were expressed in MPO content (Absorbance at OD/g wet weight of implant).

\section{Assessment of the $\mathrm{N}$-acetyl- $\beta$-D-glicosaminidase (NAG) activity}

$\mathrm{N}$-acetyl- $\beta-\mathrm{D}$-glicosaminidase lysosomal enzyme is produced by activated macrophages. This technique (Bailey, 1988) is based hydrolysis of nitofenil-p-N-acetyl- $\beta$-D-glicosamine (substrate) by $\mathrm{N}$ acetyl- $\beta$-D-glicosaminidase, releasing p-nitrophenol.

To the resulting pellet of hemoglobin, it was added $2.0 \mathrm{~mL}$ saline with $0.9 \%$ Triton X-Ioo (Promega) to $0.1 \%$ (cream). The samples were homogenized and centrifuged at 3,000 rpm for Io minutes 
at $4^{\circ} \mathrm{C}$. They were diluted $150 \mathrm{uL} 150 \mathrm{uL}$ of the supernatant in buffer citrate / phosphate and added to this solution Ioo $\mu \mathrm{l} /$ well in duplicate to the ELISA 96-well plate. Then, added Ioo $\mu 1$ of substrate (p-nitrophenyl$\mathrm{N}$-acetyl- $\beta$-D-glicosaminidase Sigma) diluted in citrate/phosphate buffer, $\mathrm{pH} 4.5$ and incubated at 37 for 30 minutes.

Finally, there were added too ul of $0.2 \mathrm{M}$ glycine buffer $\mathrm{pH}$ io.6 in the samples and the curve. The absorbance was measured by Elisa reader at 40onm. NAG activity was calculated from a standard curve of $\mathrm{p}$-nitrophenol. Results are expressed in nmol.mL-I/mg wet weight of the implant.

\section{Histological analysis of synthetic matrices}

Histological analyzes were performed to assess fibrovascular infiltrated in the synthetic implants, by quantification of mast cells (toluidine blue).

After removal of the implants, they are carefully fixed in methacarn solution. Soon, they underwent the steps of dehydration, paraffin removal, bath and embedded in paraffin blocks. From each paraffin block, two sections of $5-\mu \mathrm{m}$ were obtained. Then the sections were properly positioned on glass slides (previously silanized for better fixation of the blades cuts) and conditioned in a stove at $44^{\circ} \mathrm{C}$ for 24 hours. Then, the slides were filed subjected to specific procedures for each type of staining. For the capture and quantification of mast cells was used to capture the $40 \mathrm{X}$ objective of the microscope of Biology

Institute (INBIO-UFU) For all analyzes were captured ro different areas and the measurement was performed in program Image $\mathrm{J}$.

\section{Statistical analysis}

Statistical analysis and graphs were performed in Prism program 5. The control groups and treatments were evaluated statistically through mean, standard deviation, one way ANOVA and Newman-Keuls post-test. Statistical difference was considered for $\mathrm{p} \leq 0.05$.

\section{Results}

The animals submitted sponge implantation showed good tolerance to material under the normal pattern of behavior without signs of rejection to the implant, infection, toxicity or death.

\section{Effects of treatment on the chronic inflammation}

The inflammatory component was evaluated by enzyme activity of MPO (enzyme present in neutrophils) and NAG (enzyme present in macrophages); indirect methods for measuring of neutrophils and macrophages in the inflamed site. The inflammation was also assessed by infiltration of mast cells, an important cell type that participates in inflammatory reactions by secreting various molecules to the extracellular matrix, for example, histamine. 
Treatment with of $C$. sylvestris essential oil showed no significant change from the infiltration of neutrophils (MPO) and macrophages (NAG) in the three doses evaluated (figure I).

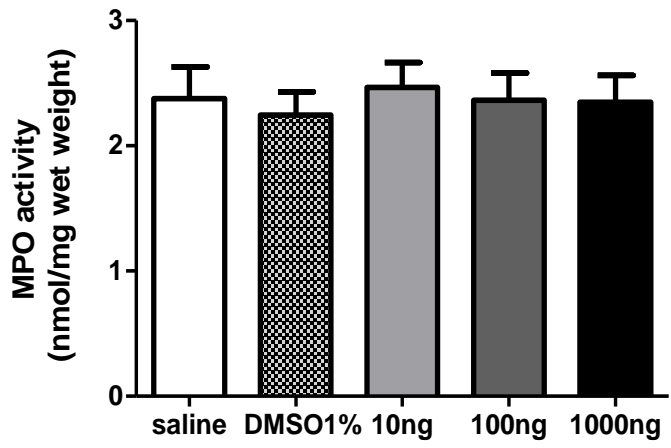

(a)

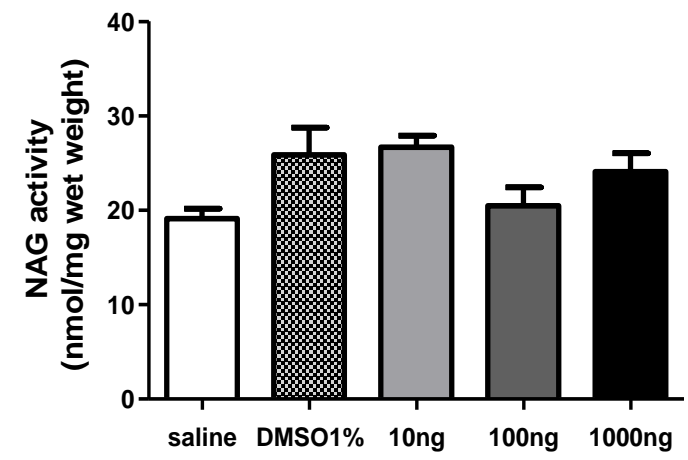

(b)

Figure I: Effect of the doses of Iong, Ioong and rooong of the C. sylvestris on the enzymatic activity of MPO (a) and NAG (b). The treatment showed no significant changes over the infiltration of neutrophils (MPO) and macrophages (NAG) on the three doses evaluated.

About mast cells, they were quantified in histological sections of the implant. Statistical analyzes, represented on figure 2, have shown that the treatment with all doses of C. sylvestris did not significantly 6 alter the number of quantified vessels in the fibrovascular capsule formed in the sponge implant. This was confirmed by morphological analysis shown in figure 3.

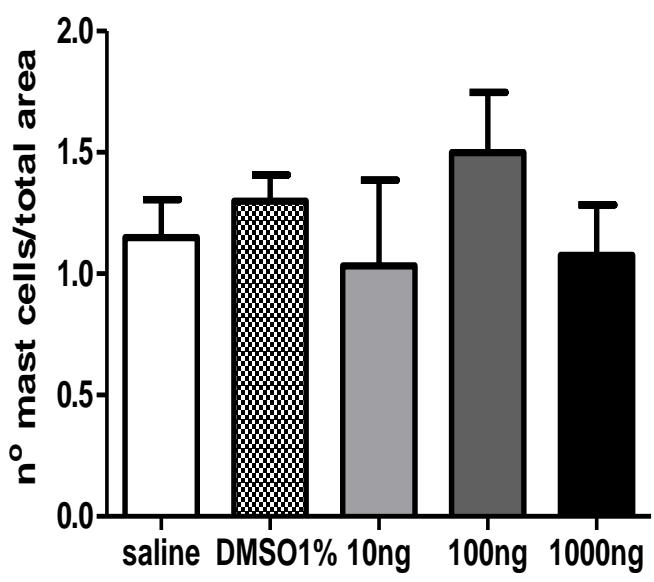

Figure 2: Effect of C. sylvestris treatment on the number of mast cells in the fibrovascular tissue: The treatment did not affect the infiltration of mast cells in all evaluated doses compared to saline group. 


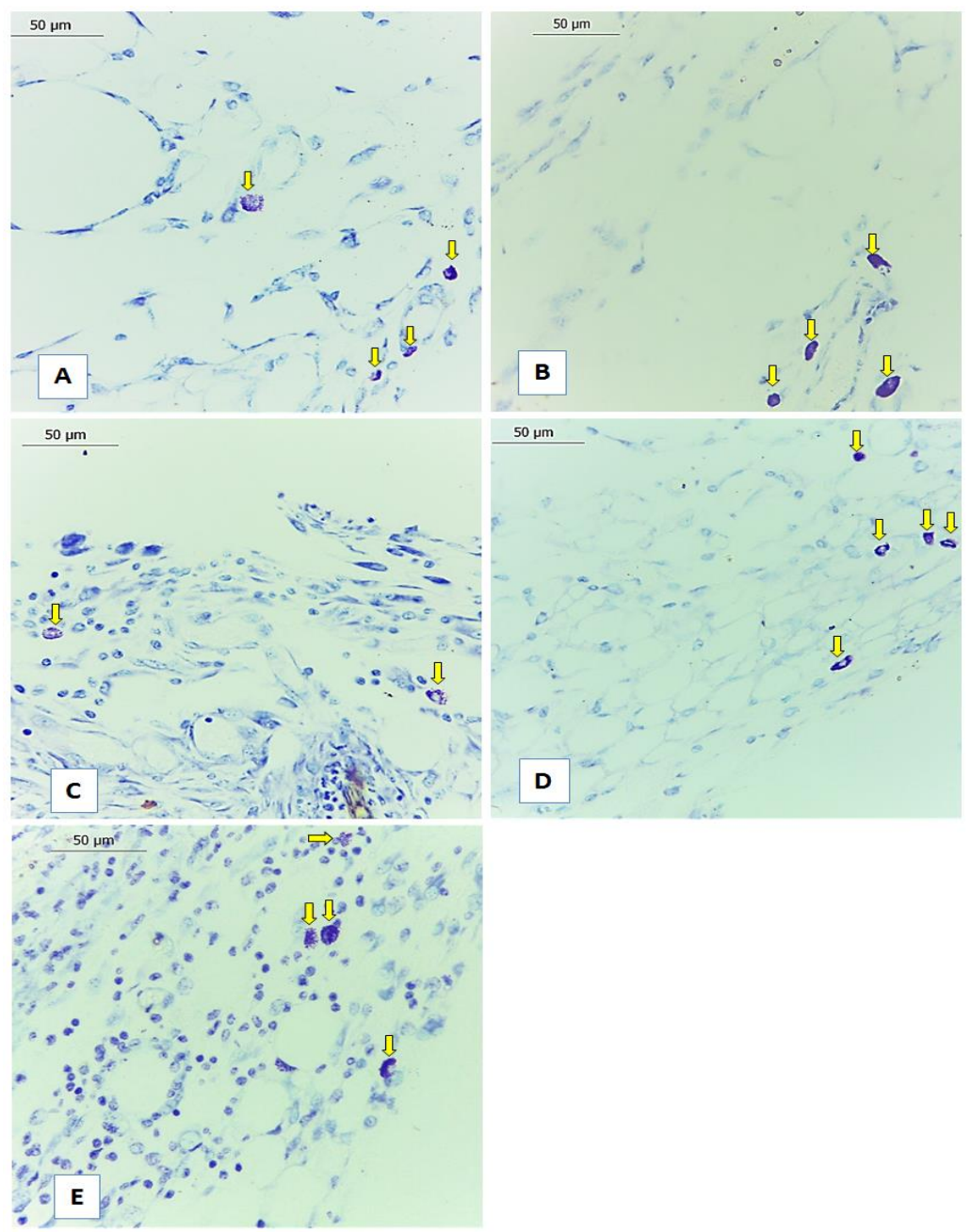

Figure 3: Histological sections ( $5 \mu \mathrm{m}$, toluidine blue staining) infiltration of fibrovascular tissue in the sponge subcutaneous implants in mice, mainly formed by inflammatory cells, fibroblasts and mast cells: saline control group (A); DMSOı\% control group(B); group treated with Iong of C. sylvestris(C); group treated with Ioong of $C$. sylvestris(D); treated group withrooong of C. sylvestris (E). There is a higher tendency to increase in number of mast cells in the treated group at a dose of roong (D). Bar $-50 \mu \mathrm{m} . \mathrm{n}=5$ animals for each group.

\section{Discussion}

The fibrovascular infiltrate was evaluated from a clinical point of view, during a chronic inflammation process. The aim of this study was to evaluate the effects of the essential oil of $C$. sylvestris at different stages of the healing process, focusing on chronic inflammation induced by synthetic implants in mice.

This was the first study to evaluate the effects of C. sylvestris in chronic inflammation in an experimental model in which the synthetic matrix (sponge) induces chronic inflammation as a foreign body type, stimulating the formation of fibrovascular tissue. This kind of model permits the infiltration and analysis of the inflammatory component, angiogenic component and the fibrogenic component on the repair phase. Within this perspective, this model makes it possible to analyse those parameters by using plants extract compounds that exhibit therapeutic potential. 
Popular uses and scientific research have highlighted the importance of C. sylvestris plant extracts and its great potential bioactive with pharmacological properties emphasized by its anti-inflammatory action (Ferreira et al., 201I). Such properties are highlighted by substances found in the essential oil, present in the leaves of C. sylvestris and attracted by its practical handling, economical and easy way to prepare (Ferreira et al., 20II).

The genus Casearia is characterized by the presence of various bioactive substances of pharmacological interest, such as flavones, essential oils, saponins, tannins, resins and antocianosídeos. These are some of the components present in the guaçatonga that exhibit bioactive action properties, popularly known: febrifuge, purifying, anti-diarrheal, cardiotonic, diuretic, analgesic and healing and antiinflammatory (TININIS, 2006; MARQUES et al, 2013). On the evaluation of the essential oil composition, extracted from leaves of Casearia sylvestris, it was discovered that it is represented by 24 compounds. Among them, the major component is a sesquiterpene called $\alpha$-zingiberene (BOU et al, 2013 TININIS, 2006; FELIPE, 2014), which is a chemical class, characteristic for its ant-inflammatory effects (FELIPE, 20I4; BOU, et al., 2013; FERREIRA et al, 20II).

However, so far the researches are insufficient to ensure the safety of Casearia sylvestris preparations based on folk knowledges. Furthermore, there is no herbal medicine with current registration on ANVISA obtained from this plant despite several pharmacological properties described in the literature (DE ARAUJO et al., 2014).

The large and widespread knowledge and use of C. sylvestris in folk medicine as an antinflammatory agent is justified by the presence of these compounds (which exhibit such property) that were biochemically detected and evaluated in previous scientific studies. Based on these data, it was postulated the hypothesis about the real anti-inflammatory effect of this plant, extrapolating to a model that involves a typical chronic inflammation.

In this study, the experiments that analyzed the effect of C. sylvestris in subcutaneous implants on mice, showed no significant change on the evaluated components present in the sponge implant (inflammatory, angiogenic and fibrogenesis of the fibrovascular tissue) in any of the treatments. The histological evaluation of the fibrovascular tissue formed into the sponges confirmed the results of the treatment en all doses evaluated.

\section{Inflammatory infiltrate}

The inflammatory component was evaluated by the activity of inflammatory enzymes present in the implant (MPO and NAG) and quantification of mast cells in histological sections. MPO activity (representing activated neutrophils) and NAG (represented by active macrophages) as well as the number 
of mast cells present in fibrovascular tissue were not affected by treatments. It shows the absence of antiinflammatory effect of $C$. sylvestris on these cell populations inflammatory.

Esteves et al., (2005) conducted a test that induces the formation of granulomatous tissue (chronic inflammation, characterized by the formation of granulomas, which consists of a cluster of defense cells in an attempt to contain the offending agent) and found that C. sylvestris not significantly inhibited this process. These data corroborate the results obtained in the present study, whose infiltration of inflammatory cells was not affected by the treatments with different doses of $C$. sylvestris. In this same work, Esteves et al., (2005), examined the formation of edema in the rat paw by using Dextran (an inflammatory agent known to induce edema mediated by the release of histamine) (Katz et al., 1984), consequent to degranulation of mast cells (Lo et al., 1982). Edema formation is because of the increased vascular permeability through the release of these substances produced by the body after an injury (Jones, 20oo). However, the results confirmed that $C$. sylvestris showed no anti-edematogenic effect, and therefore did not have effect as anti-inflammatory agent (ESTEVES et al., 2005), probably due to the inability of $C$. sylvestris to antagonize mast cells and degranulation of pharmacological active substances (histamine and serotonin, for example) (Ferreira, 2011). Thus, the results of Esteves et al., (2005) corroborate the results of current research.

Despite the C. sylvestris anti-inflammatory action to be widespread and evident in folk medicine, the used doses for the treatment $(0,3 \mu \mathrm{g} / \mathrm{kg}, 3 \mu \mathrm{g} / \mathrm{kg}, 30 \mu \mathrm{g} / \mathrm{kg})$, via local injection, under the chronic inflammation model as a granulomatous type, induced by subcutaneous synthetic implant, this study did not observe such an effect. A plausible explanation for these results route of administration involves via of treatment - an important parameter that must be kept in mind, in regard to the plant's action potential. C. sylvestris can be exploited through the development of cream for topical treatment or injected directly into the wound, as well as by infusion for oral consumption (FERREIRA et al, 2oIr; SASSIOTO et al., 2004); subcutaneous and intraperitoneal administration (ARAUJO, et al., 20ro). Possibly the oral administration of this plant, reported by the majority of the scientific works (FERREIRA et al, 2orr; SASSIOTO et al, 2004), may get the anti-inflammatory effect expected, once the plant metabolism in the liver can generate active metabolites with anti-inflammatory effect.

Another parameter that can infer the results, that concern an ant-inflammatory action of the plant, are the doses used in the treatments. Most of the reported studies were based on a single concentration of plant extracts. This approach undermines the investigation of biological effect in a dose-dependent response. In addition, the parameters for comparison for the researcher's as a point of view, becomes impaired. Thus, it was observed that the three doses evaluated in this study: o, $3 \mu \mathrm{g} / \mathrm{Kg}, 3 \mu \mathrm{g} / \mathrm{kg}, 30 \mu \mathrm{g} / \mathrm{kg}$ per day, by a concentration of Iong/ıo $\mu$ l, Ioong/ıo $\mu$ l and Iooong/ıo $\mu$ l respectively, showed no inhibitory effect on chronic inflammation induced by synthetic implant, administered in a volume of 1 o $\mu$, via injection by a syringe intra-implant. 
These results are important for the characterization of C. sylvestris action, from its essential oil (ESTEVES et al., 2005), since the majority of the investigations related about guacatonga antiinflammatory activity, has been mainly associated with its hidroalcólicos extracts (DA SILVA et al, 2008; CAVALCANTE et al., 2007; BASILE et al., 200r; BORGES et al., 200o; MORITA et al., I99r; CARVALHO et al, 1998; ORBERLIES et al, 2002; MOSADDICK et al, 2004). Potential analysis from the essential oil of $C$. sylvestris on a chronic inflammation model can help explain the anti-inflammatory activity, associated with the folk use of the plant.

\section{Conclusion}

By the results, it was observed that the three doses evaluated in this study showed no inhibitory effect on chronic inflammation induced by synthetic implant, administered via local by injection intraimplant.

\section{Acknowledgment}

The authors gratefully acknowledge the financial support of Fundação de Amparo a Pesquisa do Estado de Minas Gerais - FAPEMIG.

\section{References}

Ahmed AU (20II). An overview of inflammation: mechanism and consequences. Frontiers in Biology 6: 274-281.

Andrade S, Fan T, \& Lewis G (1987). Quantitative in-vivo studies on angiogenesis in a rat sponge model. British journal of experimental pathology 68: 755 .

Araújo F, Rocha M, Mendes J, \& Andrade S (2010). Atorvastatin inhibits inflammatory angiogenesis in mice through down regulation of VEGF, TNF- $\alpha$ and TGF- $\beta$ I. Biomedicine \& Pharmacotherapy 64: 29-34.

BASILE AC, SERTIE JAA, PANIZZA S, OSHIRO TT AND AZZOLINI CA. 199o. Pharmacological assay of Casearia sylvestris. I: Preventive anti-ulcer activity and toxicity of the leaf crude extract. J Ethnopharmacol 30: 185-197.

BORGES MH, SOARES AM, RODRIGUES VM, OLIVEIRA F, FRANSHECHI AM, RUCAVADO A, GIGLIO JR AND HOMSI-BRANDEBURGO MI. 20or. Neutralization of proteases from bothrops snake venoms by the aqueous extract fromCasearia sylvestris (Flacourtiaceae). Toxicon 39: 1863-1869.

BORGES MH, SOARES AM, RODRIGUES VM, QUINTE-RO A, LIZANO S, GUTIERREZ JM, GIGLIO JR AND HOMSI-BRANDEBURGO MI. 200o. Effects of aqueous extract of Casearia sylvestris (Flacourtiaceae) on actions of snake and bee venoms and on activity of phospholipases A 2. Comp Biochem Physiol 127: 21-30.

Bailey PJ (1988). [29] Sponge implants as models. Methods in enzymology i62: 327-334. 
Bradley PP, Christensen RD, \& Rothstein G (1982). Cellular and extracellular myeloperoxidase in pyogenic inflammation. Blood 6o: 618-622.

Capobiango RA, Vestena S, \& Bittencourt AHC (2009). Allelopathy of Joanesia princeps Vell. and Casearia sylvestris Sw. on the cultivated species. Revista Brasileira de Farmacognosia 19: 924-930.

Cassini-Vieira P, Deconte SR, Tomiosso TC, Campos PP, de Freitas Montenegro C, Selistre-de-Araújo HS, et al. (2014). DisBa-or inhibits angiogenesis, inflammation and fibrogenesis of sponge-inducedfibrovascular tissue in mice. Toxicon 92: 81-89.

CARVALHO PRF, FURLAN M, YOUNG MCM, KINGSTON DGI AND BOLZANI VS. 1998. Acetylated DNA-damaging clerodane diterpenes from Casearia sylvestris. Phytochem 49: 1659-1662.

CAVALCANTE WLG, CAMPOSA TO, PAI-SILVA MD, PEREIRA OS, OLIVEIRA CZ, SOARES AM AND GALLACCI M. 2007. Neutralization of snake venom phospholipase A2 toxins by aqueous extract of Casearia sylvestris (Flacourtiaceae) in mouse neuromuscular preparation. J Ethnopharmacol II2: 490-497.

Chandrasekharan JA, \& Sharma-Walia N (2015). Lipoxins: nature's way to resolve inflammation. Journal of Inflammation Research 8: 181-192.

DA SILVA SL, CALGAROTTO AK, CHAAR JS AND MARANGONI S. 2008a. Isolation and characterization of ellagic acid derivatives isolated from Casearia sylvestris Sw. aqueous extract with antiPLA2 activity. Toxicon 52: 655-666.

DA SILVA SL, CHAAR JS, DAMICO DCS, FIGUEIREDO PMS AND YANO T. 20o8b. Antimicrobial activity of ethanol extract from leaves of Casearia sylvestris. Pharm Biol 46: 347-35I.

DA SILVA SL, CHAAR JS, FIGUEIREDO PMS AND YANO T. 2008c. Cytotoxic evaluation of essential oil from Casearia sylvestris Sw on human cancer cells and erythrocytes. Acta Amazonica 38: 107

Duncan BB, Chor D, Aquino EML, Bensenor IM, Mill JG, Schmidt MI, et al. (20I2). Doenças crônicas não transmissíveis no Brasil: prioridade para enfrentamento e investigação. Revista de Saúde Pública 46: 126-134.

ESTEVES, I.; SOUZA, I.R.; RODRIGUES, M.; CARDOSO, L. G. V.; SANTOS, L. SILVA, J.; SERTIE, A. A., PERAZZO, F. F.; LIMA, L. M.; SCHNEEDORF, J. M.; BASTOS, J. K.; CARVALHO, J. C.T. Gastric antiulcer and anti-inflammatory activities of the essential oil from Casearia sylvestris Sw. Journal of Ethnopharmacology. V. Ior, Issues I-3, 3 October 2005, Pages 191-196

Ferreira PMP, Costa-Lotufo LV, Moraes MO, Barros FW, Martins A, Cavalheiro AJ, et al. (2oir). Folk uses and pharmacological properties of Casearia sylvestris: a medicinal review. Anais da Academia Brasileira de Ciências 83: 1373-1384.

França ISXd, Souza JAd, Baptista RS, \& Britto VRdS (2008). Medicina popular: benefícios e malefícios das plantas medicinais. Revista brasileira de enfermagem 6I: 201-208.

Gonçalves G, \& Parizotto NA (1998). Fisiopatologia da reparação cutânea: atuação da fisioterapia. Rev Bras Fisiot 21: 5-13.

GRIFFIOEN A. W., MOLENA G., Angiogenesis: potentials for pharmacologic intervention in the treatment of cancer, cardiovascular diseases, and chronic inflammation, Pharmacol Rev, 2000, 52(2):237268.

Guo S, \& DiPietro LA (2010). Factors affecting wound healing. Journal of dental research 89: 219-229. 
Hu D, Hiley C, Smither R, Gresham G, \& Fan T (1995). Correlation of 133 Xe clearance, blood flow and histology in the rat sponge model for angiogenesis. Further studies with angiogenic modifiers. Laboratory investigation; a journal of technical methods and pathology 72: 60I-6ro.

Lima RR, Costa AMR, Souza RDd, \& Gomes-Leal W (2007). Inflamação em doenças neurodegenerativas. Revista Paraense de Medicina 21: 29-34.

Lipinski LC, de Figueiredo Wouk AFP, da Silva NL, Perotto D, \& Ollhoff RD (2012). Effects of 3 topical plant extracts on wound healing in beef cattle. African journal of traditional, complementary and alternative medicines 9: 542-547.

Marques LGA, Simões ERB, Ferreira PMP, Santos MRdMC, \& Pessoa C (2013) DESENVOLVIMENTO DO POTENCIAL TECNOLÓGICO DE Casearia sylvestris. vol. 3.

MORITA H, NAKAYAMA M, KOJIMA H, TAKEYA K, ITOKAWA H, SCHENKEL EP AND MOTIDOME M. 1991. Structure and cytotoxic activity relationship of casearins, new clerodane diterpenes from Casearia sylvestris Sw. Chem Pharm Bull 39: 693-697

MOSADDIK MA, BANBURY L, FORSTER P, BOOTH R, MARKHAM J, LEACH D AND WATERMAN PG. 2004. Screening of some Australian Flacourtiaceae species for in vitro antioxidant, cytotoxic and antimicrobial activity. Phytomed II: 46r-466

OBERLIES NH ET AL. 2002. Novel bioactive clerodane diterpenoids from the leaves and twigs of Casearia sylvestris. J Nat Prod 65: 95-99.

PHILLIPS, C.L., PFEIFFER, B.J., LUGER, A.M., FRANKLIN, C.L. Novel collagen glomerulopathy in a homotrimeric type I collagen mouse (oim). Kidney Int., v.62, n. 2, p. 383-391, 2002

Plunkett S, \& Arnold F (1990). Metal affinity extraction of human hemoglobin in an aqueous polyethylene glycol-sodium sulfate two-phase system. Biotechnology techniques 4: 45-48.

PLUNKETT, M.L. \& HAILEY, J.A. An in vivo quantitative angiogenesis model using tumor cells entrapped in alginate. Lab. Invest., v. 62, n. 4, p. 510-517, 1990.

Sassioto MCP, Cardoso Filho N, Facco GG, Sodré ST, Neves N, Purisco SU, et al. (2004). Effect of Casearia sylvestris on bone repair with devitalized bovine bone matrix in rats. Acta Cirurgica Brasileira 19: 637-64I.

Silva FBd, Almeida JMd, \& Sousa SMGd (2004). Natural medicaments in endodontics: a comparative study of the anti-inflammatory action. Brazilian oral research 18: 174-179.

WATSON, T. Soft tissue repair and healing review, Tissue Repair. 2012. Disponível em: http://www.electrotherapy.org/modality/soft-tissue-repair-and-healing-review. Acesso em: I8 Jul 2014.

Yussof SJM, Omar E, Pai DR, \& Sood S (2012). Cellular events and biomarkers of wound healing. Indian Journal of Plastic Surgery 45: 220. 